\title{
51. UPPER CRETACEOUS-PALEOGENE STRATIGRAPHY OF SITES 689 AND 690, MAUD RISE (ANTARCTICA) 1
}

\author{
E. Thomas, ${ }^{2}$ E. Barrera, ${ }^{3}$ N. Hamilton, ${ }^{4}$ B. T. Huber, ${ }^{5}$ J. P. Kennett, ${ }^{6}$ S. B. O’Connell, ${ }^{2}$ J. J. Pospichal, ${ }^{7}$ V. Spieß, ${ }^{8}$ \\ L. D. Stott, ${ }^{9}$ W. Wei, ${ }^{7}$ and S. W. Wise, Jr. ${ }^{7}$
}

\begin{abstract}
This contribution summarizes the biostratigraphy of planktonic foraminifers, calcareous nannofossils, and benthic foraminifers, in combination with the magnetostratigraphy, carbon and oxygen isotope stratigraphy of benthic foraminifers, and $\mathrm{CaCO}_{3}$ stratigraphy for the Maestrichtian through Paleogene calcareous sequences recovered at Sites 689 and 690 on Maud Rise (at about $65^{\circ} \mathrm{S}$, eastern Weddell Sea, Antarctica). These data represent the southernmost calciumcarbonate record available for that interval, and thus extend the biostratigraphic and isotopic database to higher latitudes. Sites 689 and 690 form the southernmost anchor of a north-south transect through the Atlantic Ocean for Paleogene biostratigraphy and chemostratigraphy.
\end{abstract}

\section{INTRODUCTION}

During Ocean Drilling Program (ODP) Leg 113 two sites were drilled on Maud Rise, an aseismic ridge in the eastern Weddell Sea (Fig. 1A; Barker, Kennett, et al., 1988). Site 689 is located on the northeastern side of the crest of Maud Rise at $64^{\circ} 31.009^{\prime} \mathrm{S}, 3^{\circ} 05.996^{\prime} \mathrm{E}$, at a present water depth of $2080 \mathrm{~m}$. Site 690 is $116 \mathrm{~km}$ to the southwest of Site 689 , on the southwestern flank of the rise at $65^{\circ} 9.629^{\prime} \mathrm{S}, 1^{\circ} 12.30^{\prime} \mathrm{E}$, at a present water depth of $2914 \mathrm{~m}$ (Fig. 1B). At both sites, pelagic biogenic sediments were recovered, with an admixture of fine-grained terrigenous material in some intervals in the Paleocene and Maestrichtian at Site 690 (Barker, Kennett, et al., 1988, p. 190-191). The sediments range from lowermost Maestrichtian (close to the Campanian/Maestrichtian boundary) through Pliocene-Pleistocene. Core recovery was good and core-deformation minimal over most of the section, with the exception of parts of the $\mathrm{Pa}$ leocene and Cretaceous in Hole 689B (Barker, Kennett, et al., 1988).

The Upper Cretaceous through middle Eocene at both sites consists of calcareous chalks and oozes. The uppermost middle Eocene through lower Miocene is represented by a mixture of calcareous and siliceous oozes, with an upward increase of the siliceous component. The middle Miocene through PliocenePleistocene sequence is dominated by siliceous biogenic oozes, with the exception of an upper Miocene $\mathrm{CaCO}_{3}$-rich interval, and a short interval rich in the planktonic foraminifer Neogloboquadrina pachyderma close to the mud line (probably Qua-

\footnotetext{
${ }^{1}$ Barker, P. F., Kennett, J. P., et al., 1990. Proc. ODP Sci. Results, 113: College Station, TX (Ocean Drilling Program).

2 Department of Earth and Environmental Sciences, Wesleyan University, Middletown, CT 06457.

3 Department of Geological Sciences, University of Michigan, Ann Arbor, MI 48109.

${ }^{4}$ Department of Geology, University of Southampton, Southampton, SO9 $5 \mathrm{NH}$, United Kingdom.

5 Department of Paleobiology, National Museum of Natural History, Smithsonian Institution, Washington, DC 20560.

6 Marine Science Institute, University of California Santa Barbara, Santa Barbara, CA 93106.

7 Department of Geology, Florida State University, Tallahassee FL 32306.

8 Fachbereich Geowissenschaften, Universitaet Bremen, Bibliothekstrasse, 2800 Bremen, Federal Republic of Germany.

9 Department of Geological Sciences, University of Southern California, Los Angeles, CA 90089.
}

ternary). Dissolution of calcareous micro- and nannofossils generally increases upward from the middle Eocene, with strong dissolution across the Eocene/Oligocene boundary, across the lower/upper Oligocene boundary, and upward from the lower Miocene. Siliceous microfossils are present at rare to common abundances in the section from the lower upper Eocene upward, but they cannot be used for detailed biostratigraphy below the Miocene because of poor preservation and the absence of highlatitude and mid-latitude zonal markers species (see site chapters in Barker, Kennett, et al., 1988; Gersonde et al., this volume).

The Neogene sequence was dated using a combination of the zonations of different siliceous microfossil groups, and datum levels have been correlated to paleomagnetic polarity reversals (Gersonde et al., this volume, chapter 52). Calcareous microand nannofossils are too rare and poorly preserved to be of use for biostratigraphy in most of the Neogene sequence. In parts of the section where calcareous assemblages are present, they are of very low diversity and lack marker species. The stratigraphy as presented by Gersonde et al. (this volume) reveals the presence of numerous unconformities within the Neogene. The most pronounced of the Neogene unconformities occur across the Oligocene/Miocene boundary, the lower/middle Miocene boundary, and the Pliocene/Miocene boundary. At Site 689 the upper Pliocene through most of the Holocene is not represented in the section (Gersonde et al., this volume).

The Oligocene contains both calcareous and siliceous microand nannofossils, but the upper lower Oligocene through upper Oligocene cannot be zoned at high resolution with either siliceous or calcareous groups, because of the absence of markerspecies. Oligocene calcareous nannofossils and planktonic and benthic foraminifers at Maud Rise are very long-lived and show few or no stratigraphically useful first and last appearances. Nevertheless, the Oligocene planktonic foraminiferal sequence has been intercalibrated with the magnetostratigraphy (Spieß, this volume) to estimate the ages of the few datum levels observed (Stott and Kennett, this volume). The oxygen isotopic record from benthic foraminifers is useful in parts of the section, especially the globally recognized excursion to higher values just above the lower/upper Oligocene boundary, and the similarly widespread shift to heavier $\delta^{18} \mathrm{O}$-values in benthic foraminifers in the lowermost Oligocene (Kennett and Shackleton, 1976; Keigwin and Keller, 1984; Miller and Thomas, 1985; Miller et al., 1987a). Additional information on the chronology of the Oligocene may become available in the future from strontium- 

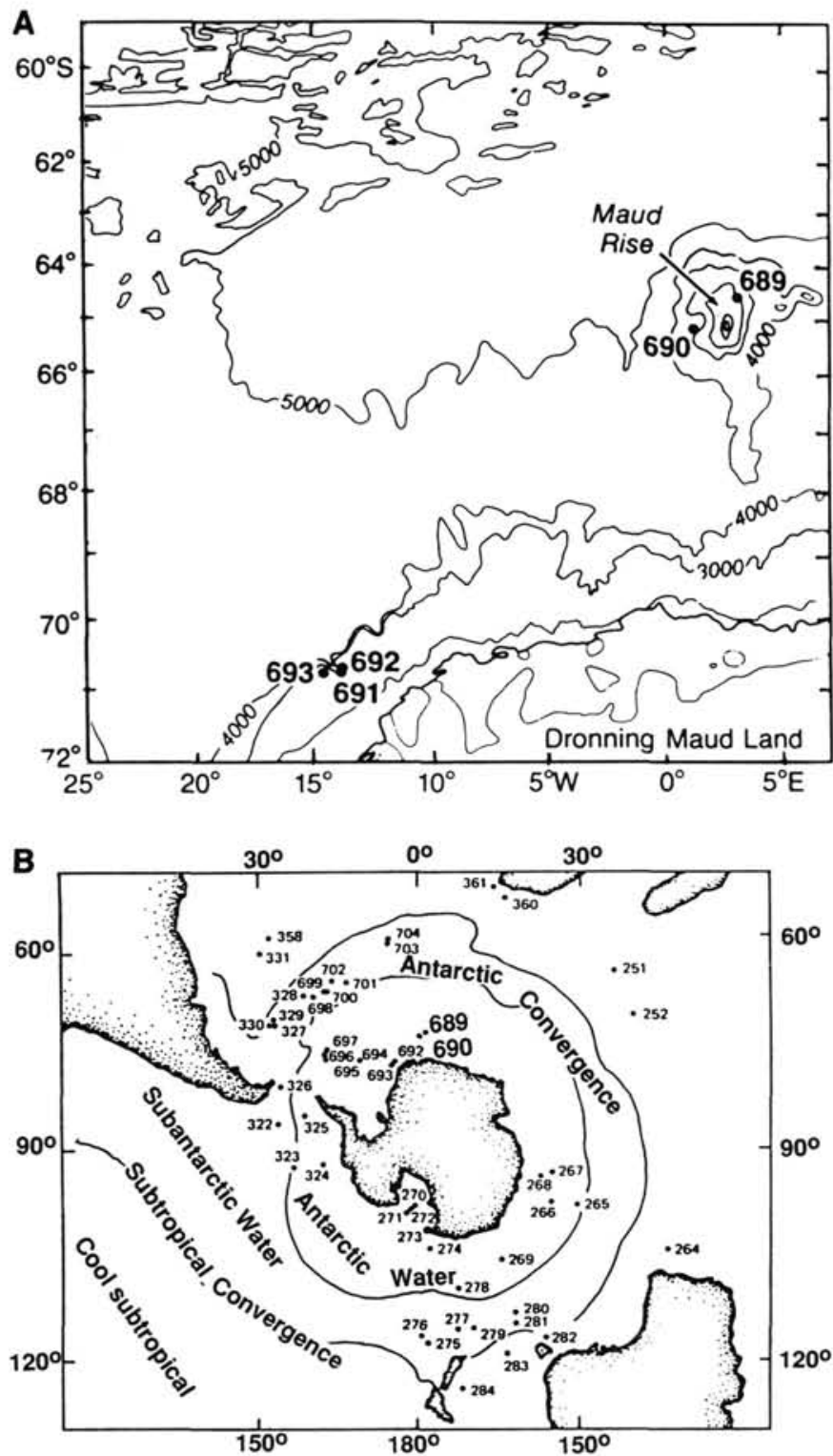

Figure 1. A. Maud Rise, eastern Weddell Sea, Antarctica, showing locations of Sites 689 and 690 . B. Location of ODP and DSDP sites at high southern latitudes.

isotope stratigraphy (Scott et al., this volume). This paper thus largely addresses the correlation between the Maestrichtian through Oligocene calcareous nannofossil and planktonic foraminiferal zonations, benthic foraminiferal assemblages, magnetostratigraphy, and benthic stable isotope and $\mathrm{CaCO}_{3}$ stratigraphy. This synthesis summarizes data presented and discussed in numerous contributions to this volume (Table 1); see these papers for methods of analysis for carbon and oxygen isotopes and $\mathrm{CaCO}_{3}$ determination.

Upper Cretaceous through Cenozoic calcareous nannofossil biostratigraphic zonations for the Southern Oceans have been summarized by Wise (1988), but the zonation has not been well established due to discontinuous coring and incomplete recovery on earlier DSDP legs. At Sites 689 and 690 the index fossils used in the low- to mid-latitude zonations by Martini (1971) and Okada and Bukry (1980) are rare or absent, especially in the Oligocene and Neogene (Wei and Wise, this volume, chapter 38). None of the zonations established for higher latitudes, such as those by Wise and Wind (1977), Wise (1983), and Wind and Wise (1983) for the Falkland Plateau region, are fully applicable, because of the extreme high latitude of Sites 689 and 690 and the absence of temperate water marker species. Wei and Wise (this volume, chapter 38) and Pospichal and Wise (this volume, chapter 32) present a Cenozoic zonation that is crosscorrelated with the zones by Okada and Bukry (1980); in this paper we show calcareous nannofossil zones by their designation in the latter scheme for ease of comparison with other localities. For the Maestrichtian Pospichal and Wise (this volume, chapter 30 ) propose an emended version of the zonation established for the Falkland Plateau Biogeographic Province by Wind (1979), and conclude that this province can be extended to the margins of Antarctica. The zonal schemes for all the MesozoicCenozoic calcareous nannofossil zones and the datum levels used to delineate zonal boundaries are shown in Table 2 .

Huber (this volume) proposes a new planktonic foraminiferal biostratigraphic zonation for the Antarctic Maestrichtian (cross-correlated with the magnetostratigraphy by Hamilton, this volume) because of the absence of marker species used in existing low- to mid-latitude zonal schemes. He describes several new species that were previously recorded (but not named) from the Falkland Plateau and the northern Antarctic Peninsula (Sliter, 1977; Krasheninnikov and Basov, 1983, 1986; Huber, 1988). Previously established zones for high-latitude sequences in New Zealand and the Antarctic Peninsula (Webb, 1971; Huber, 1988) were of limited use because of incomplete reference sections and local facies control on the distribution of some species. The zonal scheme and the datum levels used to delineate the zones are shown in Table 3.

Stott and Kennett (this volume, chapter 34 ) propose a new Paleogene planktonic foraminiferal zonation for the Antarctic, establishing fourteen biozones (numbered with the prefix AP). Existing low-latitude zonations could not be used because most index species are absent in the Antarctic. Some zones defined for the middle latitudes of the Southwest Pacific could be recognized (Srinivasan and Kennett, 1981; Jenkins and Srinivasan, 1985), although not all zones are present in sequence and some marker species are so rare that ranges could not be established with confidence. Correlation between the proposed Antarctic zonation and the low-latitude zonation was established through cross-correlation with the magnetostratigraphy at the Maud Rise sites. The mid-latitude zones have not yet been intercalibrated with the paleomagnetic time scale, so correlation between the zonation proposed for Maud Rise and the southwest Pacific is not yet clear. Names of zones in addition to the AP-letter abbreviation and the datum levels used to delineate the zones are shown in Table 3.

There is no generally accepted bathyal-abyssal benthic foraminiferal stratigraphic zonation for the Mesozoic-Cenozoic, although Tjalsma and Lohmann (1983) proposed several informal zones for the abyssal-lower middle bathyal upper Paleocene-Eocene. Benthic foraminiferal faunas from the Maud Rise sites are subdivided into eight assemblages (Thomas, this volume), and no formal zones are proposed. Recently, Berggren and Miller (1989) proposed a tentative zonation for the benthic foraminiferal upper-middle bathyal realm and another zonation for the abyssal through lower bathyal realm. The boundaries between the benthic foraminiferal assemblages at Maud Rise appear to be coeval (within the limited time-resolution available) with the boundaries between the abyssal benthic foraminiferal zones. Although there appears to be a good time-correlation between assemblage-boundaries at Maud Rise and zonal boundaries as proposed by Berggren and Miller (1989), many of the specific zonal markers proposed by the latter authors cannot be used at the Maud Rise sites because they are rare or absent, or because of differences in stratigraphic ranges. The assemblages are com- 
pared with the proposed abyssal benthic foraminiferal zones of Berggren and Miller (1989) in Table 4, together with the datum levels used to delineate the assemblages at the Maud Rise sites.

Paleomagnetic data for the Maud Rise sites were obtained by Hamilton (this volume) for the uppermost Mesozoic, and by Spieß (this volume, chapter 21) for the Cenozoic; see the papers by these authors for details on methods of measurement (Table 1). No data are yet available for the interval between 210 and 240 mbsf at Site 690 (Cores 113-690C-11X through -14X; lower Paleocene). We used the geomagnetic polarity time scale as established by Berggren et al. (1985) and modified by Aubry et al. (1988). Spieß (this volume, chapter 21) used a slightly different subchron nomenclature than that of LaBrecque et al. (1983), using only one level of subchron numbering (thus Subchron C5A, C5AA, C5AB, etc., were re-named C5AN/R-1, etc.; see Fig. 2 in Spieß, this volume, chapter 21, for details). In this paper, ages for the Mesozoic part of the geomagnetic polarity timescale were taken after Berggren et al. (1985), for consistency with the Cenozoic sequence. Hamilton (this volume, chapter $20)$, however, uses a correlation with the geomagnetic polarity timescale by Kent and Gradstein (1985); according to this timescale sediments corresponding to the latest $2.2 \mathrm{~m}$.y. of the Campanian were recovered at Site 689. Similarly, sediments deposited during the last $1.2 \mathrm{~m}$.y. of the Campanian rest on basement at Site 690 (based upon an age of the Campanian/Maestrichtian boundary of $74.5 \mathrm{Ma}$ ). Huber (this volume, chapter 31) uses the geomagnetic polarity timescale after Haq et al. (1987); according to this timescale no Campanian sediments were recovered at Site 690 , and sediments corresponding to about 0.5 m.y. of Campanian time are present at Site 689 .

\section{Discussion of the Age Model}

The data on the downhole locations of the zonal boundaries and paleomagnetic reversals are presented in Tables 5 through 11 and Figures 2 and 3 . An overview of the location of the epoch boundaries at both sites is provided in Table 12. We used the following procedure: first all zonal boundaries were plotted vs. sub-bottom depth, with the uncertainty-interval (the distance between the two samples used to locate the boundary) and the age for that boundary. Depth intervals and midpoints are shown in Tables 5 through 11 .

Ages for the calcareous nannofossil zonal boundaries follow Berggren et al. (1985), as emended by Aubry et al. (1988); see Table 2. Ages for the planktonic foraminiferal zonal boundaries were derived from the intercalibrated magnetobiostratigraphy in Berggren et al. (1985) and Aubry et al. (1988) as presented in Figure 4 in Stott and Kennett (this volume, chapter 34), and listed in Table 3. Ages for the boundaries between benthic foraminiferal assemblages were derived from correlation with the benthic zonation proposed by Berggren and Miller (1989). These authors do not provide a direct correlation between the benthic zones and the geomagnetic polarity timescale, but they correlated the benthic zonation and standard low-latitude planktonic foraminiferal zones (Table 4).

The next step was to plot the position and the ages of paleomagnetic reversal boundaries as shown in Tables 5 and 6 and Figures 8 and 9 in Spieß (this volume, chapter 21), and in Table 1 and Figures 4 and 5 in Hamilton (this volume). The paleomagnetic assignment was compared with the biostratigraphic data; some adjustments in the evaluation of the paleomagnetic reversals were made after this comparison, resulting in the final paleomagnetic stratigraphy as given in Spieß (this volume, chapter 21). All data were plotted in a Shaw-plot (Fig. 4; depth at Site 689 vs. depth in Site 690 ) to check for consistency in the location of datum levels between the two sites. Finally, age-depth plots were derived for the two sites (Figs. 5, 6).
Figures 2 and 3 represent the first attempt to accommodate all data in one schedule and show the interpretation of the paleomagnetic stratigraphy that appears to be in best agreement with most of the data from Leg 113 and published time scales. Comparison of all data sets shows overall good agreement, but obviously some problems remain, especially in the details of the correlation between the various microfossil and nannofossil groups. These problems are partially caused by the fact that this is the first attempt at high southern latitude zonation, and we do not yet have a full insight into the diachroneity of the datum levels. In addition, interpretation of some intervals of the section remains questionable because of the presence of unconformities at one (or, for one interval, possibly at both) of the sites. The most prominent Paleogene unconformities at the two sites, however, are not coeval between the sites.

One problem concerns the location of the Eocene/Oligocene boundary at Site 689 . At Site 689 this interval appears to be well represented in the sediments, but different interpretations of the correlation between the biozones and the paleomagnetic record are possible. No comparison with data at Site 690 is possible, because at that site there is an unconformity across the Eocene/ Oligocene boundary (see below). In this paper we opted for a correlation of the upper part of Chron $16 \mathrm{~N}$ with planktonic foraminiferal zonal boundary AP12/AP13 (the last appearance of Globigerinatheka index), which occurs slightly above the first appearance of the calcareous nannofossil Isthmolithus recurvus). Thus the age of the last appearance (LA) of G. index is 38.4 $\mathrm{Ma}$, the first appearance (FA) of I. recurvus $38.9 \mathrm{Ma}$. This is considerably older than the age of the FA of $I$. recurvus as assigned in Berggren et al. $(1985 ; 37.8 \mathrm{Ma})$, but fairly close to the age of 38.2 Ma as recorded by Monechi and Thierstein (1985) for this datum level in the Italian sections. The FA of this taxon may be diachronous (see Wei and Wise, this volume, and Stott and Kennett, this volume, chapter 34 , for a discussion).

A major unconformity occurs at about $202.5 \mathrm{mbsf}$ at Site 689 (Core 113-689B-22X); as a result of this unconformity there is little to no lower Eocene sediment present at that site. The unconformity appears to be at a color change in the sediment, at 113-689B-22X-4, $55 \mathrm{~cm}$; the interval between that level and 113$689 \mathrm{~B}-22 \mathrm{X}-4,20 \mathrm{~cm}$, however, contains strongly reworked material (see core photograph on p. 159 in Barker, Kennett, et al., 1988). The duration of this unconformity appears to be at least 6-7 Ma (from about 50 to about 56 or $57 \mathrm{Ma}$; Zone CP13 in contact with Zone CP8; Zone AP8 on Zone AP5; Chron C21R on $\mathrm{C} 24 \mathrm{R})$.

Another unconformity is present lower in the section. According to the benthic and planktonic foraminiferal biostratigraphy this unconformity appears to be present between Cores 113-689B-24X and -25X (there was very poor recovery on Core 113-689B-24X), but higher resolution work on calcareous nannofossils established that this unconformity is preserved within the topmost part of Core 113-689B-25 at 226.63 mbsf (Table 5). The duration of this unconformity appears to be at least 2-3 m.y. (60-63 Ma; Zone CP7 on CP3; Zone AP3 on AP1b).

There appears to be another unconformity across the Cretaceous/Tertiary boundary in Hole 689B: calcareous nannofossil zone CP1a is not represented $(66.0-66.4 \mathrm{Ma})$, and neither is paleomagnetic Chron C29R (66.17-66.74 Ma), so that at least about $0.5 \mathrm{~m}$.y. of time is not represented in the sediments. The presence of an unconformity across the boundary is confirmed by the absence of an Iridium-anomaly (Michel et al., this volume, chapter 12), whereas such an anomaly is present at Site 690 . There appears to be a discrepancy between the thickness of the lowermost Cenozoic planktonic foraminiferal Zone $\operatorname{AP} \alpha$ at Sites 689 and 690: this zone is thicker at Site 689 (where there is an unconformity) than at Site 690 (where the record appears to 


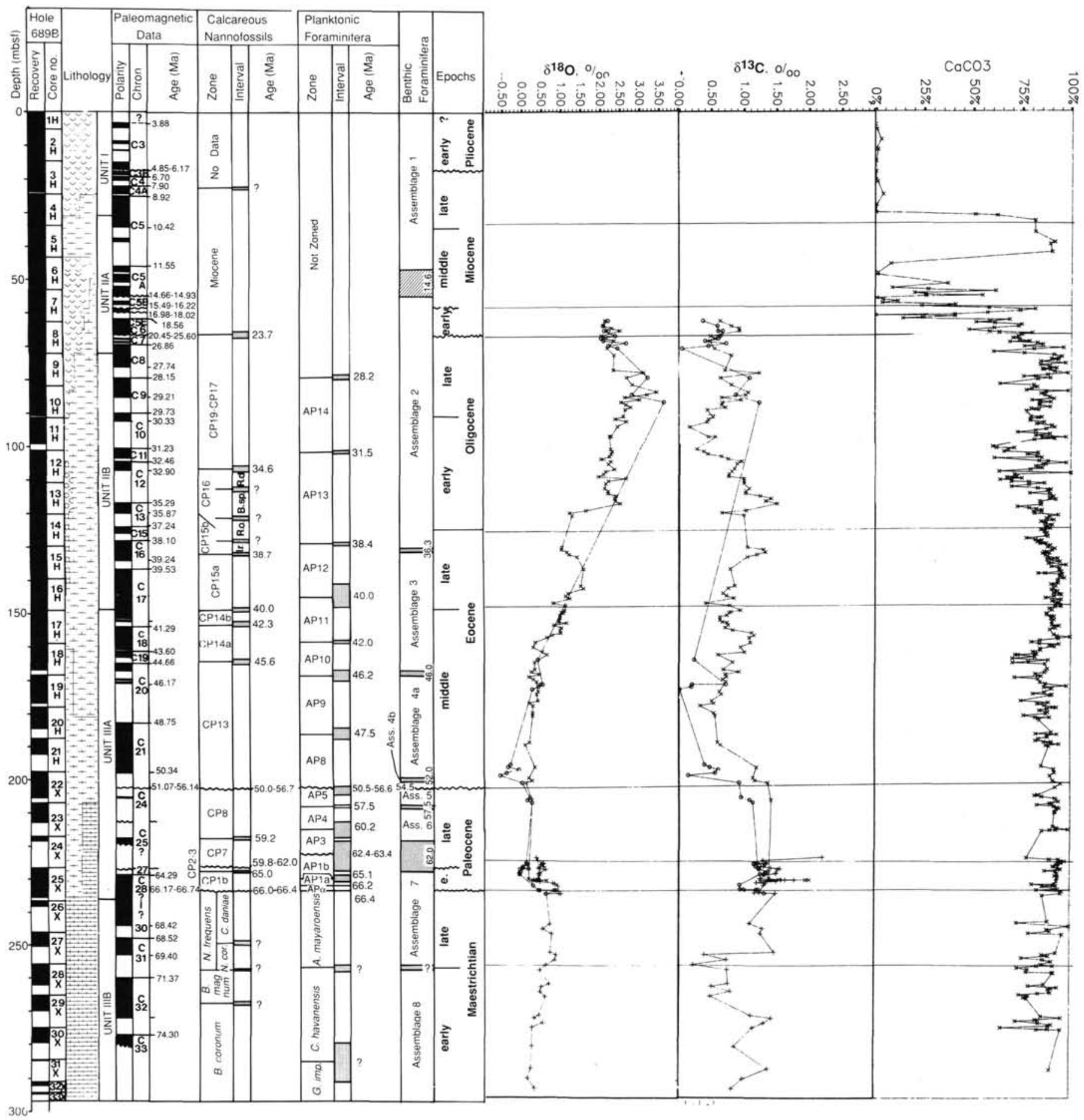

Figure 2. Compilation of magnetostratigraphic, biostratigraphic, benthic foraminiferal isotope, and $\mathrm{CaCO}_{3}$ data for Site 689 . Data on core recovery, lithologic units, and graphic lithology after Barker, Kennett, et al. (1988). See text for description of sources and procedures, Tables 2-5 for data. R. d. = Reticulofenestra daviesii Zone; B. sp. = Blackites spinosus Zone; R. o. = Reticulofenestra oamaruensis Zone; I. r. = Isthmolithus recurvus Zone; N. frequens = Nephrolithus frequens Zone; . daniae = Cribrosphaerella daniae Subzone; N. corystus = Nephrolithus corystus Subzone; B. magnum = Biscutum magnum Zone; B. coronum = Biscutum coronum Zone; A. mayaroensis = Abathomphalus mayaroensis Zone; G. havanensis = Globotruncatella havanensis Zone; $\mathrm{G}$. impensus = Globigerinelloides impensus Zone. For the isotopic data: $\mathrm{x}=$ Nuttallides spp.; $\mathrm{o}=$ C $i$ bicidoides spp.; + = Gavelinella spp. 


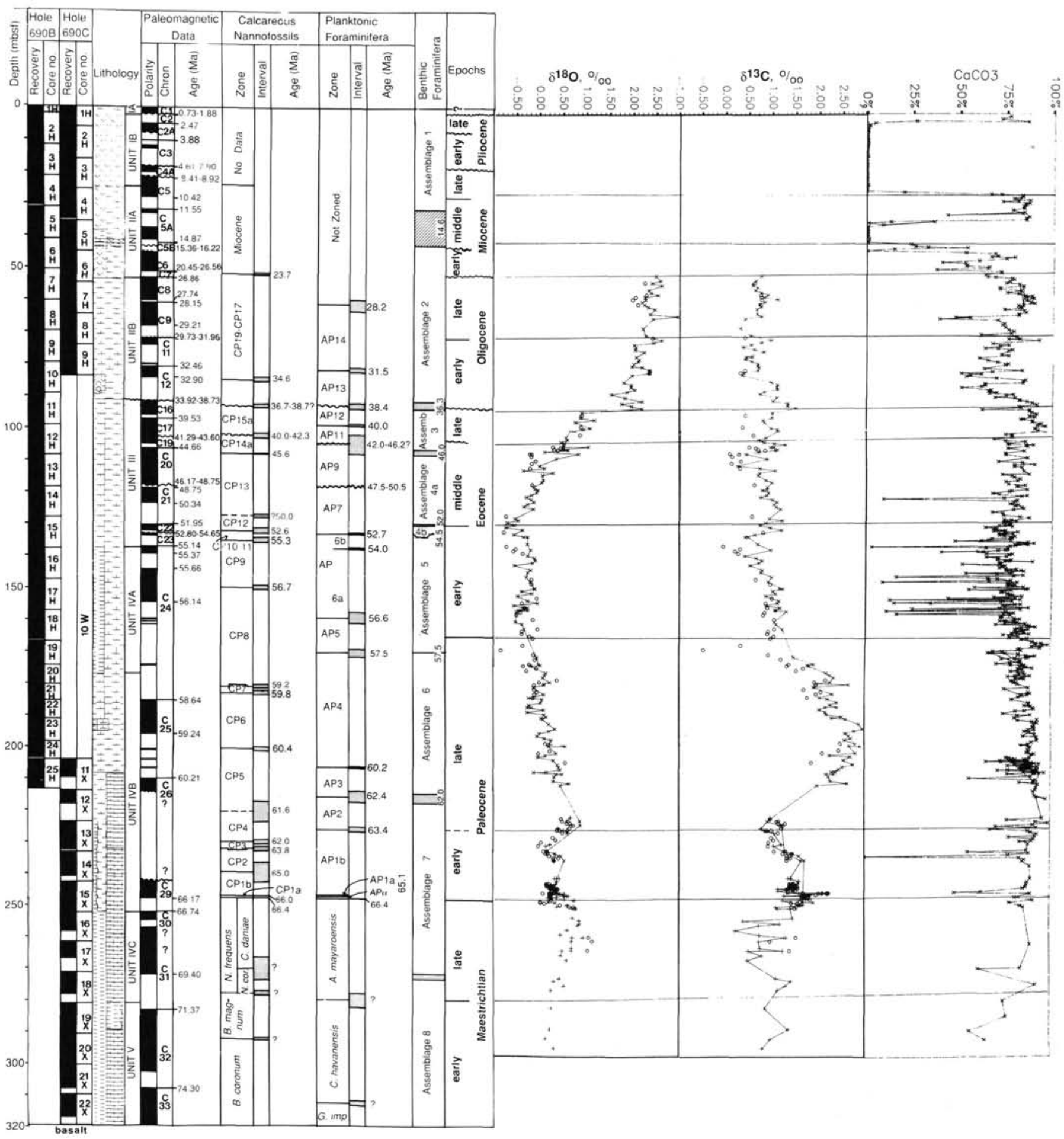

Figure 3. Compilation of magnetostratigraphic, biostratigraphic, benthic foraminiferal isotope, and $\mathrm{CaCO}_{3}$ data for Site 690 . Data on core recovery, lithologic units, and graphic lithology after Barker, Kennett, et al. (1988). See text for description of sources and procedures, Tables 2-5 for data. N. frequens = Nephrolithus frequens Zone; C. daniae = Cribrosphaerella daniae Subzone; N. corystus = Nephrolithus corystus Subzone; B. magnum = Biscutum magnum Zone; B. coronum = Biscutum coronum Zone; A. mayaroensis = Abathomphalus mayaroensis Zone; $\mathrm{G}$. havanensis = Globotruncatella havanensis Zone; G. impensus = Globigerinelloides impensus Zone. For the isotopic data: $\mathrm{x}=$ Nuttallides spp.; o $=$ Cibicidoides spp.; + = Gavelinella spp. 


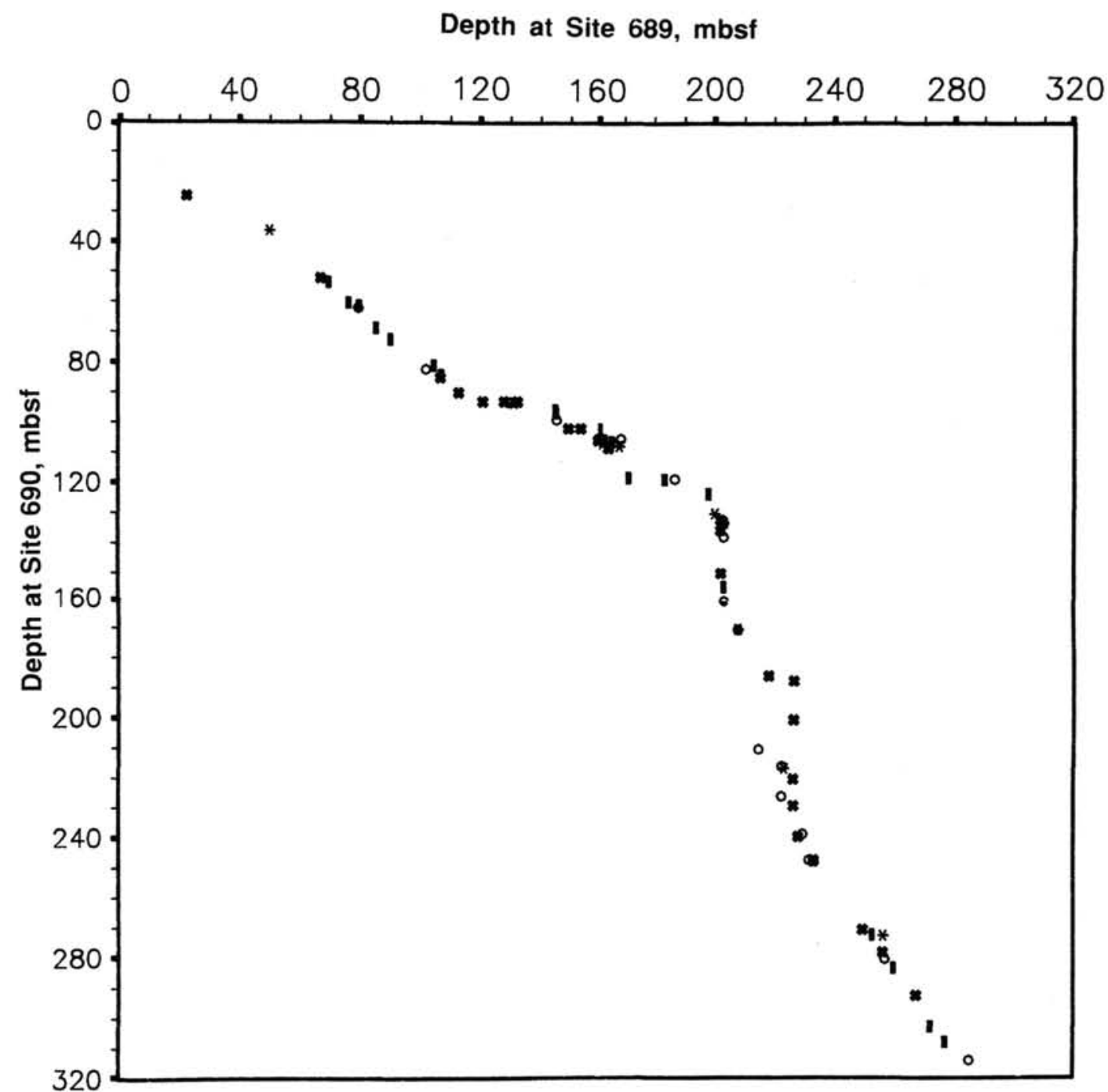

Figure 4. Depths below seafloor at Site 689 plotted vs. those at Site 690; data as in Tables 2-5. I = paleomagnetic data; $\mathrm{O}=$ planktonic foraminiferal data; $\mathrm{X}=$ calcareous nannofossil data; ${ }^{*}=$ benthic foraminiferal data.

be complete, see below). This apparent discrepancy might be explained by the fact that Stott and Kennett (this volume, chapter 34) chose to use the first common occurrence rather than the first occurrence of Subbottina pseudobulloides to define the boundary between Zones AP $\alpha$ and APla, because of the strong bioturbation in the Maud Rise sequences.

There is no evidence for the presence of unconformities in the Cretaceous, although this cannot be established with certainty because of poor recovery in many cores. Interpretation of the paleomagnetic data suggests a fairly uniform sedimentation rate of between 5 and $6 \mathrm{~m} / \mathrm{m}$.y. (Hamilton, this volume, chapter 20). Overall, unconformities at Site 689 are largely present in the Paleocene and lower Eocene, whereas the middle through upper Eocene are well-represented in the sediments, and there are no apparent unconformities in the Maestrichtian.

At Site 690 the most prominent Paleogene unconformities have different ages than those at Site 689, and are present mainly in the upper-middle to upper Eocene. At Site 690 there is an unconformity across the Eocene/Oligocene boundary, and part of the lowermost Oligocene and the upper Eocene is not represented. The unconformity is easily recognized visually (see Figure 7 in Site 690 chapter, Barker, Kennett, et al., 1988) in Core 113-690B-11 H-3, 73-90 cm (about $92.8 \mathrm{mbsf}$ ), and for about 40 $\mathrm{cm}$ above this level there is considerable reworking. The unconformity was recognized by Wei and Wise (this volume), Stott and Kennett (this volume, chapter 34), and Thomas (this volume), although there are minor differences in interpretation of the exact location and duration. These differences may largely result from the strong reworking just above the lithologic unconformity. The interpretation of the paleomagnetic record in combination with the different biozonations suggests that the unconformity represents a large part of Chrons 13 through 15 (about 38.7-33.9 Ma). The benthic foraminiferal oxygen isotopic record in combination with the biostratigraphic data suggests that the unconformity extends at least from the Eocene/ Oligocene boundary across the increase in benthic $\delta^{18} \mathrm{O}$-values of about 1 per mil at about 36-35 Ma (Kennett and Stott, this volume).

The exact duration of this unconformity, however, is difficult to ascertain, because at least one other unconformity is present within a few tens of meters, in Core 113-690B-12H. The exact level of this second unconformity is difficult to determine, because there are discrepancies between its location as established by lithologic changes, calcareous nannofossils, planktonic foraminifers, and benthic foraminifers. There is considerable reworking throughout Core 113B-690-12 $\mathrm{H}$ and in the lower part 
A

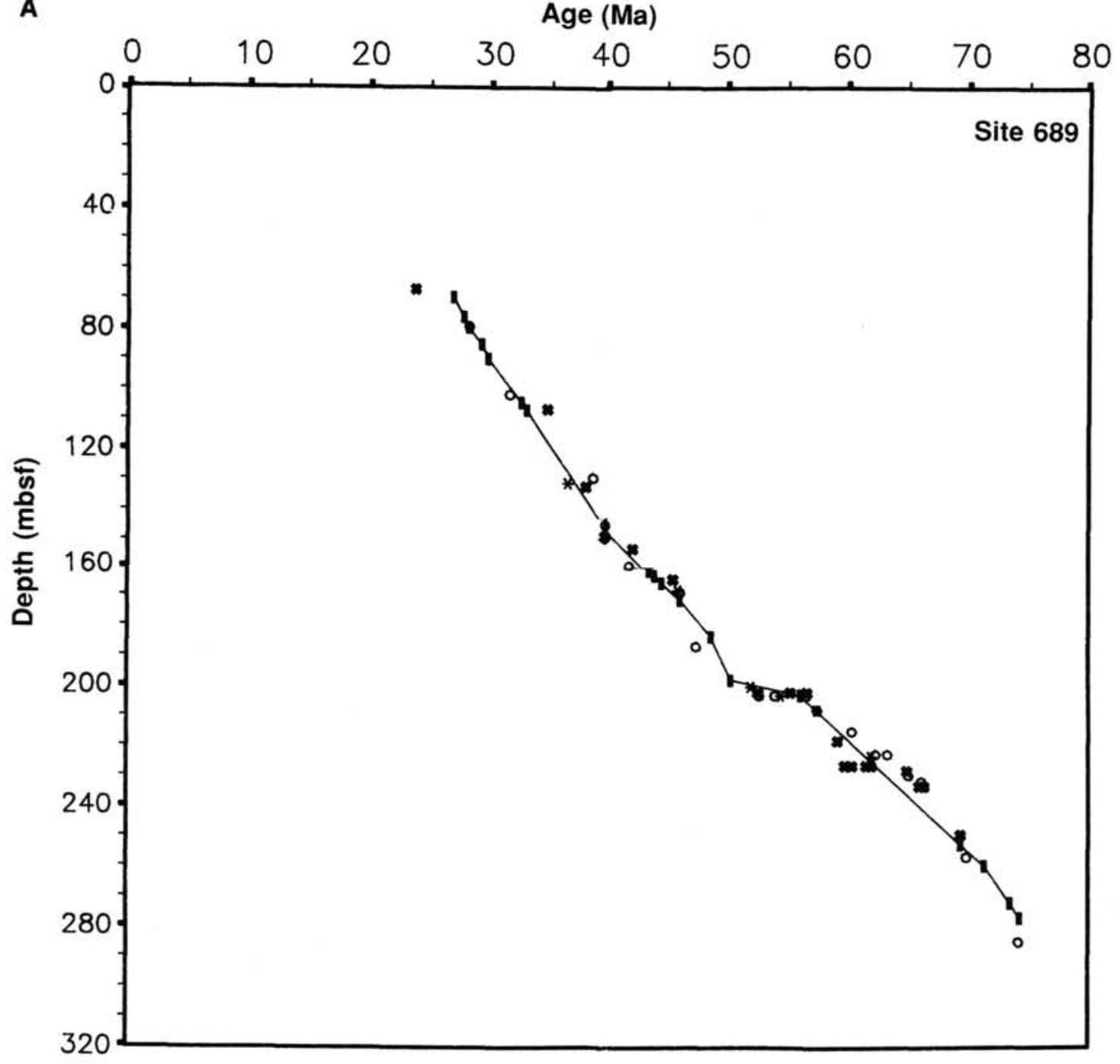

Figure 5. Age-depth plots, constructed using the data as listed in Tables 2 through 5 and shown in Figures 2 and 3. A. Site 689. B. Sit- 690 . Symbols same as in Figure 4.

of Core 113B-690B-11H (below the unconformity described above). It is possible that the material in this interval (92.5$108.0 \mathrm{mbsf}$ ) represents slivers of material separated by several unconformities; the age of this section is most probably late Eocene (corresponding to part of Chrons 16-17), but the exact agemodel for the interval between about 92.5 and 108.0 mbsf cannot be established. The duration of this lower unconformity is probably on the order of $2 \mathrm{~m}$.y. (Fig. 3).

There may be another unconformity in Core 113-690B-15H, or there may be a strongly condensed section. An interval in the lower part of Section 113-690B-15H-4 (indicated in the corelogs in Barker, Kennett, et al., 1988 as drilling-disturbed) probably represents a thin (about $35 \mathrm{~cm}$ ) debris-flow, with an erosional lower boundary at about 133 mbsf. Benthic foraminifers indicate considerable reworking in this interval, with many specimens showing abrasion and fungal drilling holes. Calcareous nannofossil zones CP10-11 appear to be too thin to be fully represented; a continuous sedimentation rate over the interval is $1.3 \mathrm{~m} . / \mathrm{m}$.y. Such a low sedimentation rate suggests the presence of unconformities. Spieß (this volume, chapter 21) indicates the possible presence of an unconformity covering the lower part of Chron 22 and the upper part of Chron 23 (52.80-54.65 Ma).
This interpretation agrees well with the nannofossil and benthic foraminiferal zonations, but Stott and Kennett (this volume, chapter 34) did not recognize an unconformity in this interval. They instead suggested that the lower part of Core 113-690B$15 \mathrm{H}$ be assigned to Chron 22, not to part of Chron 23 (compare Fig. 3 with Fig. 1 in Stott and Kennett, this volume, chapter 34), and that the top of Core 113-690B-16 H be placed in Chron 23 (not in Chron 24, as in Fig. 3). This interpretation would mean that calcareous nannofossil Zone CP9 extends across Chron 23 and into the lower part of Chron 22, which disagrees with the correlation between nannofossil zone CP9 with Chron 24, Zones CP10-11 with Chrons 23-22 in Aubry et al. (1988). The interpretation by Stott and Kennett may be correct, because the nannofossil species might have diachronous first and last appearances; presently, however, there is no convincing evidence available for such strong diachroneity in that interval. There is no opportunity to cross-check on the correlation between biozones and the geomagnetic polarity time scale at Site 689 , because at that site the interval is not represented in the sediments (where there is an unconformity from about 50 to $56 \mathrm{Ma}$, see above). If the unconformity from 53 to $55 \mathrm{Ma}$ is indeed present at Site 690 , then this interval is the only interval of the Cenozoic 
B Age (Ma)

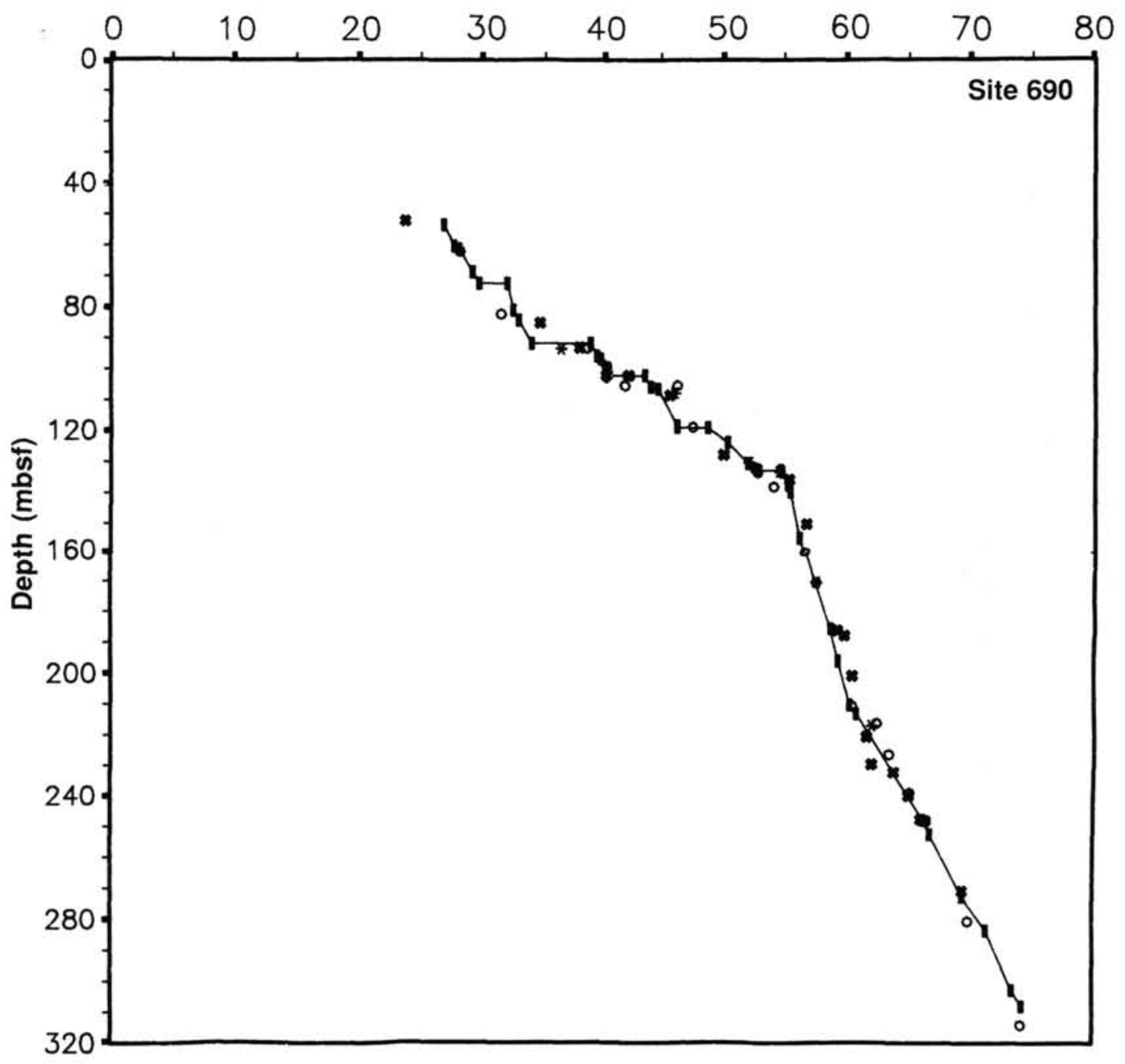

Figure 5 (continued).

not represented in the sediments at Sites 689 and 690, requiring a re-interpretation of the planktonic foraminiferal intercalibration with the paleomagnetic record.

The lower part of the middle Eocene and the lower Eocene through upper Paleocene are well represented at Site 690 , in contrast with Site 689 (see above). The overall sedimentationrate during Chron C24 (55.14-58.64 Ma, 137.33-185.45 mbsf) was $13.8 \mathrm{~m} / \mathrm{m} . y$., the highest recorded for any deep-sea sediment sequence recovered by DSDP-ODP across this time interval. At this high-sedimentation-rate site the strong decrease in $\delta^{13} \mathrm{C}$ values in the benthic foraminiferal record (Miller et al., 1987 b) is correlated closely with the major benthic foraminiferal extinction (Thomas, this volume, chapter 35) and the planktonic foraminiferal zonal boundary between Zones AP4 and AP5 (Stott and Kennett, this volume, chapter 34). The planktonic foraminiferal boundary occurs $50 \mathrm{~cm}$ (corresponding to about 37,000 years) higher than the benthic foraminiferal extinction. At Site 689 the benthic foraminiferal extinction and the planktonic foraminiferal zonal boundary are both represented in the sediment just below the major unconformity at 202.5 mbsf, and the planktonic zonal boundary at that site also occurs slightly higher than the benthic datum level of major extinction.
Calcareous nannofossil Zone CP7 (the Heliolithus riedelii Zone) is extremely thin (about $45 \mathrm{~cm}$ ) at Site 690, which is inconsistent with the high sedimentation rates. This zone is thicker at Site 689 , where part of it may be missing in an unconformity; thus the markers for these zonal boundaries may not be reliable at high southern latitudes. The discrepancy between the sites is clearly illustrated in Figure 4, where the points representing the nannofossil data fall off the line connecting the other data. This discrepancy might be the result of poor recovery at Site 689 , Core 613-689C-24X.

No other unconformities can be resolved at Site 690, although the sedimentation rate appears to be very low just above the Cretaceous/Tertiary boundary (Hamilton, this volume, chapter 20): the Cretaceous/Tertiary (K/T) boundary is very close to the upper boundary of Chron C29R. The boundary itself appears to be well-represented, because all calcareous nannofossil and planktonic foraminiferal zones were found, as was an iridium anomaly (Michel et al., this volume, chapter 12). A comparison of the planktonic foraminiferal zones at Sites 689 and 690 suggests that the upper boundary of the lowest Cenozoic planktonic foraminiferal zone, Zone $\mathrm{AP} \alpha$, may not be coeval between the sites, because this zone is thicker at Site 689 than at Site 690 , whereas paleomagnetic, nannofossil and geochemical evidence 
indicates that the section is more complete at Site 690 (as described above).

Paleomagnetic evidence suggests that the Cretaceous part of the section at Site 690 was deposited at fairly uniform sedimentation rates of about $7.3 \mathrm{~m} / \mathrm{m}$.y., somewhat higher than at Site 689. This is in agreement with biostratigraphic data, which show that all zones are slightly thicker at Site 690 than at Site 689.

\section{CONCLUSIONS}

Data on calcareous micro- and nannofossils from Sites 689 and 690 show that the combined sections of Sites 689 and 690 offer an almost complete record of the Maestrichtian through Paleogene, with the possible exception of an interval in the early Eocene (53-55 Ma). We have established correlations between the biostratigraphic zonations and the paleomagnetic, isotopic and $\mathrm{CaCO}_{3}$ records at the sites, thus extending the Paleogene stratigraphic record to higher southern latitudes than ever before.

\section{REFERENCES}

Aubry, M.-P., Berggren, W. A., Kent, D. V., Flynn, J. J., Klitgord, K. D., Obradovich, J. D., and Prothero, D. R., 1988. Paleogene chronology: an integrated approach. Paleoceanography, 3:707-742.

Barker, P. F., Kennett, J. P., et al., 1988. Proc. ODP, Init. Repts., 113: College Station, TX (Ocean Drilling Program).

Berggren, W. A., Kent, D. V., Flynn, J. J., and Van Couvering, J. A. 1985. Cenozoic Geochronology. Geol. Soc. Am. Bull., 96:1407-1418.

Berggren, W. A., and Miller, K. G., 1989. Cenozoic bathyal and abyssal benthic foraminiferal zonations. Micropaleontology, 35:308-320.

Haq, B. U., Hardenbol, J., and Vail, P. R., 1987. The new chronostratigraphic basis of Cenozoic and Mesozoic sea level cycles. Cushman Found. Foram. Res., Spec. Publ., 24: Fig. 2.

Huber, B. A., 1988. Upper Campanian-Paleocene foraminifera from the James Ross Island Region (Antarctic Peninsula). Geol. Soc. Am. Mem., 169:163-251.

Jenkins, D. G., and Srinivasan, M. S., 1985. Cenozoic planktonic foraminifers of the southwest Pacific. In Kennett, J. P., von der Borch, C.C., et al., Init. Repts. DSDP, 90: Washington (U.S. Govt. Printing Office), 795-834.

Keigwin, L. D., and Keller, G., 1984. Middle Oligocene climatic change from equatorial Pacific DSDP Site 77. Geology, 12:16-19.

Kennett, J. P., and Shackleton, N. J., 1976. Oxygen isotopic evidence for the development of the psychrosphere, $38 \mathrm{Myr}$ ago. Nature, 260: 215-215.

Kent, D. V., and Gradstein, F. M., 1985. A Cretaceous and Jurassic geochronology. Geol. Soc. Am. Bull., 96:1419-1427.

Krasheninnikov, V. A., and Basov, I. A., 1983. Stratigraphy of Cretaceous sediments of the Falkland Plateau based on planktonic foraminifers, Deep Sea Drilling Project Leg 71. In Ludwig, W. J., Krasheninnikov, V. A., et al., Init. Repts. DSDP, 71: Washington (U.S. Govt. Printing Office), 789-820.

1986. Late Mesozoic and Cenozoic stratigraphy and geological history of the South Atlantic high latitudes. Palaeogeogr., Palaeoclimatol., Palaeoecol., 55:145-188.

LaBrecque, J. L., Hsu, K. J., Carman, M. F., Karpoff, A., McKenzie, J. A., Percifal, S. F., Petersen, N. P., Pisciotto, K. A., Schreiber, E., Tauxe, L., Tucker, P., Weissert, H. J., and Wright, R., 1983. DSDP
Leg 73: contributions to Paleogene stratigraphy in nomenclature, chronology and sedimentation rates. Palaeogeogr., Palaeoclimatol., Palaeoecol., 42:91-125.

Martini, E., 1971. Standard Tertiary and Quaternary calcareous nannoplankton zonation. Proc. 2nd Planktonic Conf., Roma 1970, 2:739785.

Miller, K. G., Fairbanks, R. G., and Mountain, G. S., 1987a. Tertiary isotope synthesis, sea level history, and continental margin erosion. Paleoceanography, 2:1-20.

Miller, K. G., Janecek, T. R., Katz, M. E., and Keil, D. J., 1987b. Abyssal circulation and benthic foraminiferal changes near the Paleocene/Eocene boundary. Paleoceanography, 2:741-761.

Miller, K. G., and Thomas, E., 1985. Late Eocene to Oligocene benthic foraminiferal isotopic record, Site 574, equatorial Pacific. In Mayer, L., Theyer, F., et al., Init. Repts. DSDP, 85: Washington (U.S. Govt. Printing Office), 771-777.

Monechi, S., and Thierstein, H. R., 1985. Late Cretaceous-Eocene nannofossil and magnetostratigraphic correlations near Gubbio, Italy. Mar. Micropaleontol., 9:419-440.

Okada, H., and Bukry, D., 1980. Supplementary modification and introduction of code numbers to the low-latitude coccolith biostratigraphic zonation (Bukry 1973, 1975). Mar. Micropaleontol., 5:321325.

Sliter, W. V., 1977. Cretaceous foraminifera from the southwest Atlantic Ocean, Leg 36, Deep Sea Drilling Project. In Barker, P. F., Dalziel, I. W. D., et al., Init. Repts. DSDP, 36: Washington (U.S. Govt. Printing Office), 519-573.

Srinivasan, M. S., and Kennett, J. P., 1981. Neogene planktonic foraminiferal biostratigraphy and evolution: equatorial to subantarctic, South Pacific. Mar. Micropaleontol., 6:449-533.

Tjalsma, R. C., and Lohmann, G. P., 1983. Paleocene-Eocene bathyal and abyssal benthic foraminifera from the Atlantic Ocean. Micropaleontology, Spec. Publ., 4:1-94.

Webb, P. N., 1971. New Zealand Late Cretaceous foraminifera and stratigraphy: a summary. N. Z. J. Geol. Geophys., 14:795-828.

Wind, F. H., 1979. Maestrichtian-Campanian nannoflora provinces of the southern Atlantic and Indian Oceans. Am. Geophys. Union M. Ewing Ser., 3: 123-137.

Wind, F. H., and Wise, S. W., 1983. Correlation of upper Campanianlower Maestrichtian calcareous nannofossil assemblages in drill and piston cores from the Falkland Plateau, southwest Atlantic Ocean. In Ludwig, W. J., Krasheninnikov, V. A., et al., Init. Repts. DSDP, 71: Washington (U.S. Govt. Printing Office), 551-563.

Wise, S. W., 1983. Mesozoic and Cenozoic calcareous nannofossils recovered by Deep Sea Drilling Project Leg 71 in the Falkland Plateau region, Southwest Atlantic Ocean. In Ludwig, W. J., Krasheninnikov, V. A., et al., Init. Repts. DSDP, 71: Washington (U.S. Govt. Printing Office), 481-550.

1988. Mesozoic-Cenozoic history of calcareous nannofossils in the region of the Southern Ocean. Palaeogeogr., Palaeoclimatol. Palaeoecol., 67:157-159.

Wise, S. W., and Wind, F. H., 1977. Mesozoic and Cenozoic calcareous nannofossils recovered by DSDP Leg 71 in the Falkland Plateau region, Southwest Atlantic Ocean. In Ludwig, W. J., Krasheninnikov, V. A., et al., Init. Repts. DSDP, 71: Washington (U.S. Govt. Printing Office), 269-294.

Date of initial receipt: 11 September 1989

Date of acceptance: 22 November 1989

Ms 113B-194 
Table 1. Sources of information used in the construction of Figures 2 through 5 and Tables 2 through 5. All names refer to papers in this volume.

\begin{tabular}{|c|c|}
\hline Source & Type of data \\
\hline Site chapters: Barker, Kennett, et al., 1988 & Core number, recovery \\
\hline Site chapters: Barker, Kennett, et al., 1988 & Lithology, lithological units \\
\hline Spiess, chapter 21 & Polarity reversals, chron boundaries, Cenozoic \\
\hline Hamilton, chapter 20 & Polarity reversals, chron boundaries, Mesozoic \\
\hline Wei and Wise, chapter 38 & Calcareous nannofossils, middle Eocene-Pleistocene \\
\hline Pospichal and Wise, chapter 30 & Calcareous nannofossils, Paleocene-middle Eocene \\
\hline Pospichal and Wise, chapter 32 & Calcareous nannofossils, Cretaceous/Tertiary boundary \\
\hline Pospichal and Wise, chapter 37 & Calcareous nannofossils, Maestrichtian \\
\hline Stott and Kennett, chapter 34 & Planktonic foraminifers, Paleogene \\
\hline Huber, chapter 31 & Planktonic foraminifers, Maestrichtian \\
\hline Thomas, chapter 35 & Benthic foraminifers, Maestrichtian-Pliocene \\
\hline Kennett and Stott, chapter 49 & $\delta^{13} \mathrm{C}, \delta^{18} \mathrm{O}$, benthic foraminifers, Paleogene \\
\hline Stott and Kennett, chapter 47 & $\delta^{13} \mathrm{C}, \delta^{18} \mathrm{O}$, benthic foraminifers, Cretaceous/Tertiary boundary \\
\hline Barrera and Huber, chapter 46 & $\delta^{13} \mathrm{C}, \delta^{18} \mathrm{O}$, benthic foraminifers, Maestrichtian \\
\hline O'Connell, chapter 55 & $\mathrm{CaCO}_{3}$ values, bulk sediment, Maestrichtian-Pliocene \\
\hline
\end{tabular}

Table 2. Standard calcareous nannofossil zones, calcareous nannofossil zones proposed for Leg 113, datum levels used to designate the zones, and ages. $\mathbf{L A}=$ last appearance; $F A=$ first appearance; $L C A=$ last common appearance. Ages as derived from correlation between the standard nannofossil zones and the geomagnetic polarity timescale in Berggren et al. (1985), as emended in Aubry et al. (1988).

\begin{tabular}{|c|c|c|c|}
\hline Standard zones & Zone, Leg 113 & Event & $\begin{array}{l}\text { Age } \\
\text { (Ma) }\end{array}$ \\
\hline CP19 & Top Chiasmolithus altus Zone & LCA $C$. altus & $?$ \\
\hline CP16/CP17-19 & Top Reticulofenestra daviesii Zone & LA $R$. umbilica & 34.6 \\
\hline Upper CP16 & Top Blackites spinosus Zone & LA Isthmolithus recurvus & $?$ \\
\hline Lower CP16 & Top Reticulofenestra oamaruensis Zone & LA $R$. oamaruensis & $?$ \\
\hline Upper CP15 & Top Isthmolithus recurvus Zone & FA $R$. oamaruensis & $?$ \\
\hline $\mathrm{CP} 15 \mathrm{a} / \mathrm{CP} 15 \mathrm{~b}$ & Top Chiasmolithus oamaruensis Zone & FA I. recurvus & 37.8 \\
\hline $\mathrm{CP} 14 \mathrm{~b} / \mathrm{CP} 15 \mathrm{a}$ & Top Discoaster saipanensis Zone & FA C. oamaruensis & 40.0 \\
\hline $\mathrm{CP} 14 \mathrm{a} / \mathrm{CP} 14 \mathrm{~b}$ & Top Reticulofenestra reticulata Zone & LA $C$. solitus & 42.3 \\
\hline Middle CP 14a & Top Reticulofenestra umbilica Zone & FA $R$. reticulata & $?$ \\
\hline CP13/CP14a & Top Nannotetrina quadrata Zone & FA $R$. umbilica & 45.6 \\
\hline $\mathrm{CP} 12 / \mathrm{CP} 13$ & Top Discoaster sublodoensis Zone & LA D. lodoensis & 50.0 \\
\hline CP10-11/CP12 & Top $D$. lodoensis $/ T$. orthostylus Zone & FA D. sublodoensis & 52.6 \\
\hline CP9/CP10-11 & Top Discoaster diastypus Zone & FA D. lodoensis & 55.3 \\
\hline CP8/CP9 & Top Discoaster multiradiatus Zone & FA Tribrachiatus bramlettei & 56.7 \\
\hline CP7/CP8 & Top Heliolithus riedelii Zone & FA $D$. multiradiatus & 59.2 \\
\hline $\mathrm{CP} 6 / \mathrm{CP} 7$ & Top Discoaster mohleri Zone & FA $H$. riedelii & 59.8 \\
\hline CP5/CP6 & Top Heliolithus kleinpellii Zone & FA D. mohleri? & 60.4 \\
\hline CP4/CP5 & Top Fasciculithus tympaniformis Zone & LA $F$ tympaniformis & 61.6 \\
\hline $\mathrm{CP} 3 / \mathrm{CP} 4$ & Top Ellipsolithus macellus Zone & FA $F$ tympaniformis & 62.0 \\
\hline $\mathrm{CP} 2 / \mathrm{CP} 3$ & Top Chiasmolithus danicus Zone & LA $C$, danicus & 63.8 \\
\hline $\mathrm{CP} 1 \mathrm{~b} / \mathrm{CP} 2$ & Top Cruciplacolithus tenuis Zone & FA C. danicus & 65.0 \\
\hline $\mathrm{CP} 1 \mathrm{a} / \mathrm{CP} 1 \mathrm{~b}$ & Top Cruciplacolithus primus Zone & FA C. tenuis & 66.0 \\
\hline $\mathrm{K} / \mathrm{T}$ & Top Cribrosphaerella danica Subzone & FA Biantholithus sparsus & 66.4 \\
\hline Top Nephrolithus corystus Subzone & & LA $N$. corystus & ? \\
\hline Top Biscutum magnum Zone & & L.A B. magnum & ? \\
\hline Top Biscutum coronum Zone & & LA B. coronum & $?$ \\
\hline
\end{tabular}


Table 3. Zones, datum levels, and ages for planktonic foraminifers, Leg 113. $\mathbf{L A}=$ last appearance; FA = first appearance; FCA $=$ first common appearance. Ages as derived from correlation of faunal zones in the composite record of Sites 689 and 690 (Stott and Kennett, this volume, chapter 34) and Huber (this volume) with the paleomagnetic record in SpieB (this volume, chapter 21) and Hamilton (this volume), according to the geomagnetic polarity time scale in Berggren et al. (1985), with corrections as in Aubry et al. (1988).

\begin{tabular}{|c|c|c|}
\hline Zonal boundary & Event & $\begin{array}{c}\text { Age } \\
\text { (Ma) }\end{array}$ \\
\hline Top AP14 & LA Globigerina labiacrassata & 28.2 \\
\hline AP13/AP14 & LA Subbotina angiporoides & 31.5 \\
\hline AP12/AP13 & LA Globigerinatheka index & 38.4 \\
\hline AP11/AP12 & LA Subbotina linaperta & 40.0 \\
\hline AP10/AP11 & LA Acarinina coalingensis & 42.0 \\
\hline AP9/AP10 & FA Globigerinatheka index & 46.2 \\
\hline AP8/AP9 & FA Pseudohastigerina micra & 47.5 \\
\hline AP7/8 & FA Acarinina bullbrooki & $50.5 ? ?$ \\
\hline AP6b/AP7 & FA Acarinina coalingensis & 52.7 \\
\hline AP6a/AP6b & FA Acarinina pentacamerata & 54.0 \\
\hline AP5/AP6a & FA Acarinina wilcoxensis berggrenii & 56.6 \\
\hline AP4/AP5 & FA Planorotalites australiformis & 57.5 \\
\hline AP3/AP4 & FA Acarinina praepentacamerata & 60.2 \\
\hline AP2/AP3 & FA Muricoglobigerina mckannai & 62.4 \\
\hline AP1b/AP2 & FA Planorotalites imitatus & 63.4 \\
\hline APla/AP1b & FA Subbotina inconstans & 65.1 \\
\hline $\mathrm{APa} / \mathrm{APla}$ & FCA Subbotina pseudobulloides & 66.2 \\
\hline $\mathrm{K} / \mathrm{T}$ & LA Abathomphalus mayaroensis & 66.4 \\
\hline Top Globotruncanella havanensis Zone & FA A. mayaroensis & 69.9 \\
\hline Top Globigerinelloides impensus Zone & LA $G$. impensus & 74.2 \\
\hline
\end{tabular}

Table 4. Zones proposed by Berggren and Miller (1989), assemblages in Leg 113 material, datum levels, and ages for benthic foraminiferal datum levels. $\mathbf{L A}=$ last appearance; $\mathbf{L C A}=$ last common appearance; $\mathbf{F A}=$ first appearance. Ages as derived from ages of planktonic foraminiferal zones according to Berggren et al. (1985) and corrected by Aubry et al. (1988), correlated with benthic foraminiferal zonal boundaries in Berggren and Miller (1989).

\begin{tabular}{cllc}
\hline $\begin{array}{c}\text { Zones } \\
\text { (Berggren and Miller) }\end{array}$ & \multicolumn{1}{c}{ Leg 113 } & \multicolumn{1}{c}{ Event } & $\begin{array}{c}\text { Age } \\
\text { (Ma) }\end{array}$ \\
\hline In AB10 & Assemblage 1/2 & LCA Stilostomella spp. & 14.6 \\
AB7/AB8 & Assemblage 2/3 & LA Bulimina elongata & 36.3 \\
AB5/AB6 & Assemblage 3/4a & LA Bulimina semicostata & 46.0 \\
AB4/AB5 & Assemblage 4a/4b & FA Bulimina semicostata & 52.0 \\
AB3/AB4 & Assemblage 4b/5 & FA Siphogenerinoides eleganta & 54.5 \\
AB2/AB3 & Assemblage 5/6 & LA Gavelinella beccariiformis & 57.5 \\
AB1/AB2 & Assemblage 6/7 & FA Bulimina thanetensis & 62.0 \\
- & Assemblage 7/8 & FA Alabamina creta & $?$ \\
\hline
\end{tabular}

Table 5. Sample levels in the cores and depth below seafloor for datum levels of calcareous nannofossils, Site 689. UNC. = unconformity.

\begin{tabular}{llcc}
\hline \multicolumn{1}{c}{ Event } & \multicolumn{1}{c}{ Samples (Hole 689B) } & Depth (mbsf) & Midpoint \\
\hline top Miocene & $689 \mathrm{~B}-3-5,139-141 \rightarrow 3-6,29-31$ & $22.20-22.60$ & 22.40 \\
top CP17-19 & $8-3,30-32 \rightarrow 8-4,30-32-\mathrm{UNC}$. & $65.81-67.31$ & 66.56 \\
CP16/CP17-19 & $12-4,29-31 \rightarrow 12-5,29-31$ & $105.80-107.30$ & 106.55 \\
R. daviesii/B. spinosus & $13-1,130-132 \rightarrow 13-2,130-132$ & $111.91-113.41$ & 112.66 \\
B. spinosus/R. oamaruensis & $13-7,28-30 \rightarrow 14-1,130-132$ & $119.89-121.51$ & 120.70 \\
R. oamaruensis/I. recurvus & $14-5,130-132 \rightarrow 14-6,30-32$ & $127.51-128.01$ & 127.76 \\
CP15a/CP15b & $15-2,30-32 \rightarrow 15-2,131-133$ & $131.71-132.72$ & 132.21 \\
CP14b/CP15a & $16-7,29-31 \rightarrow 17-1,29-31$ & $148.70-149.40$ & 149.05 \\
CP14a/14b & $17-3,29-31 \rightarrow 17-4,29-31$ & $152.40-153.90$ & 153.15 \\
$R$. reticulata/R. umbilica & $17, \mathrm{CC}-18-1,31-33$ & $158.80-159.12$ & 158.96 \\
CP14a/CP13 & $18-4,31-44 \rightarrow 18-5,31-33$ & $163.62-165.12$ & 164.37 \\
CP12-13/CP8 & $22-3,132-133 \rightarrow 22-4,30-32-\mathrm{UNC}$. & $201.82-202.37$ & 202.07 \\
CP7/CP8 & $24-1,116-118 \rightarrow 24$, CC & $218.07-218.56$ & 218.32 \\
CP2-3/CP7 & $25-1,5-6 \rightarrow 25-1,18-19-$ UNC. & $226.65-226.78$ & 226.72 \\
CP1b/CP2-3 & $25-2,6-7 \rightarrow 25-2,39-40$ & $228.16-228.49$ & 228.33 \\
K/T-CP1b/C. daniae & $25-5,81-82 \rightarrow 25-5,83-84-\mathrm{UNC}$. & $233.42-233.43$ & 233.43 \\
C. daniae/N. corystus & $27-3,29-31 \rightarrow 27$, CC & $249.29-250.18$ & 249.74 \\
N. corystus/B. magnum & $28-1,29-31 \rightarrow 28-1,135-137$ & $255.90-256.96$ & 256.43 \\
B. magnum/B. coronum & $29-2,28-30 \rightarrow 29-2,130-132$ & $266.99-268.01$ & 267.50 \\
\hline
\end{tabular}


Table 6. Sample levels in the cores and depth below seafloor for datum levels of calcareous nannofossils, Site $\mathbf{6 9 0}$. UNC. = unconformity.

\begin{tabular}{|c|c|c|c|}
\hline Event & $\begin{array}{c}\text { Samples } \\
\text { (Hole 690B, C) }\end{array}$ & $\begin{array}{l}\text { Depth } \\
\text { (mbsf) }\end{array}$ & Midpoint \\
\hline top Miocene & $690 \mathrm{~B}-4-2,130-132 \rightarrow 4-3,28-30$ & $24.21-24.69$ & 24.55 \\
\hline top CP17-19 & $7-1,130-132 \rightarrow 7-2,28-30$ UNC. & $51.71-52.19$ & 51.95 \\
\hline CP16/CP17-19 & $10-4,26-28 \rightarrow 10-5,26-28$ & $84.17-85.67$ & 84.92 \\
\hline R. daviesii/B. spinosus & $11-1,29-31 \rightarrow 11-1,130-132$ & $89.40-90.41$ & 89.91 \\
\hline B. spinosus/C. oamaruensis & $11-3,29-31 \rightarrow 11-3,130-132$-UNC. & $92.40-93.41$ & 92.90 \\
\hline CP15a/CP14b & $12-2,130-132 \rightarrow 12-3,29-31-$ UNC. & $101.61-102.10$ & 101.86 \\
\hline R. reticulata/R. umbilica & $12-5,29-31 \rightarrow 12-6,29-31$ & $105.10-106.60$ & 105.85 \\
\hline $\mathrm{CP} 14 \mathrm{a} / \mathrm{CP} 13$ & $12-7.29-31 \rightarrow 12, \mathrm{CC}$ & $108.10-108.50$ & 108.30 \\
\hline CP13/CP12?? & $14-6,130-132 \rightarrow 14-7,27-29$ & $127.31-127.78$ & 127.55 \\
\hline CP11-10/CP12 & $15-3,30-32 \rightarrow 15-4,30-32$ & $131.41-132.91$ & 132.16 \\
\hline CP9/CP10-11 & $15-5,30-32 \rightarrow 15-6,30-32$ & $134.41-135.91$ & 135.66 \\
\hline CP8/CP9 & $17-2,28-30 \rightarrow 17-3,28-30$ & $149.29-150.79$ & 150.04 \\
\hline CP7/CP8 & $22-1,28-30 \rightarrow 22-1,130-132$ & $185.49-186.51$ & 186.00 \\
\hline $\mathrm{CP} 6 / \mathrm{CP} 7$ & $22-2,28-30 \rightarrow 22-3,28-30$ & $186.99-188.49$ & 187.74 \\
\hline CP5/CP6?? & $24-2,29-31 \rightarrow 24-3,29-31$ & $200.00-201.50$ & 200.75 \\
\hline CP4/CP5 & $690 \mathrm{C}-12-3,25-27 \rightarrow 13-1,28-30$ & $217.16-223.89$ & 220.53 \\
\hline CP3/CP4 & $13-4,129-131 \rightarrow 13-5,129-131$ & $229.40-230.90$ & 229.40 \\
\hline $\mathrm{CP} 2 / \mathrm{CP} 3$ & $13-6,28-30 \rightarrow 13, \mathrm{CC}$ & $231.39-232.58$ & 231.99 \\
\hline $\mathrm{CP} 1 \mathrm{~b} / \mathrm{CP} 2$ & $14-3,28-30 \rightarrow 15-1,2-3$ & $236.49-242.93$ & 239.71 \\
\hline CPla/CP1b & $15-3,151-152 \rightarrow 15-4,1-2$ & 247.41-247.42 & 247.41 \\
\hline $\mathrm{K} / \mathrm{T}$ & $15-4,41.5 \rightarrow 15-4,41.8$ & $247.815-247.818$ & 247.82 \\
\hline C. daniae/N. corystus & $17, \mathrm{CC} \rightarrow 18-2,127-129$ & 266.83-274.17 & 270.50 \\
\hline N. corystus/B. magnum & $18-5,36-38 \rightarrow 18, C C$ & $277.76-278.37$ & 278.07 \\
\hline B. magnum/B. coronum & $20-1,133-135 \rightarrow 20-2,28-30$ & $292.14-292.59$ & 292.37 \\
\hline
\end{tabular}

Table 7. Sample levels in the cores and depth below seafloor for datum levels of planktonic foraminifers, Site 689. UNC. = unconformity.

\begin{tabular}{lllr}
\hline \multicolumn{1}{c}{ Event } & \multicolumn{1}{c}{ Samples (Hole 689B) } & \multicolumn{1}{c}{$\begin{array}{c}\text { Depth } \\
\text { (mbsf) }\end{array}$} & Midpoint \\
\hline top AP14 & \multicolumn{1}{c}{$9-5,35-39 \rightarrow 9-6,35-39$} & $78.47-79.22$ & 79.22 \\
AP13/AP14 & $12-1,35-39 \rightarrow 12-1,110-114$ & $101.37-102.12$ & 101.75 \\
AP12/AP13 & $14-6,110-114 \rightarrow 14$, CC & $128.82-129.29$ & 129.29 \\
AP11/AP12 & $16-2,35-37 \rightarrow 16$, CC & $141.26-149.09$ & 145.18 \\
AP10/AP11 & 17, CC $\rightarrow 18-1,36-38$ & $158.80-159.17$ & 158.98 \\
AP9/AP10 & $18, \mathrm{CC} \rightarrow 19-2,35-39$ & $166.85-170.37$ & 168.61 \\
AP8/AP9 & $20, \mathrm{CC} \rightarrow 21-1,110-114$ & $184.46-188.96$ & 186.69 \\
AP5/AP8 & $22-4,35-39 \rightarrow 22-5,35-39-\mathrm{UNC}$. & $202.37-203.87$ & 203.12 \\
AP4/AP5 & $23-1,35-39 \rightarrow 23-1,108-112$ & $207.57-208.27$ & 207.92 \\
AP3/AP4 & $23, \mathrm{CC} \rightarrow 24-1,35-39$ & $212.85-217.27$ & 215.06 \\
AP1b/AP3 & $24, \mathrm{CC} \rightarrow 25-1,90-92-\mathrm{UNC}$. & $218.56-227.51$ & 222.79 \\
AP1a/AP1b & $25-2,58-62 \rightarrow 25-3,135-138$ & $228.70-230.97$ & 229.84 \\
AP $\alpha / A P 1 a$ & $25-4,62-66 \rightarrow 25-4,93-95$ & $231.74-232.03$ & 231.89 \\
K/T & $25-5,79-81 \rightarrow 25-5,91-94$ & $233.39-233.54$ & 233.46 \\
A. mayaroensis/G. havanensis & $28-1,76-80 \rightarrow 28-2,80-82$ & $256.37-257.91$ & 257.14 \\
$G$. havanensis/G. impensus & $30, \mathrm{CC}-32-1,41-43$ & $279.45-291.22$ & 285.34 \\
\hline
\end{tabular}


Table 8. Sample levels in the cores and depth below seafloor for datum levels of planktonic foraminifers, Site 690 . UNC. = unconformity.

\begin{tabular}{llrr}
\hline \multicolumn{1}{c}{ Event } & \multicolumn{1}{c}{ Samples (Holes 690B, C) } & Depth (mbsf) & Midpoint \\
\hline top AP14 & $690 \mathrm{~B}-7, \mathrm{CC} \rightarrow 8-3,36-40$ & $60.10-63.48$ & 61.79 \\
AP13/AP14 & $10-2,36-40 \rightarrow 10-3,36-40$ & $81.28-82.78$ & 82.03 \\
AP12/AP13 & $11-3,35-39 \rightarrow 11-4,35-39-$ UNC. & $92.47-93.97$ & 93.22 \\
AP11/AP12 & $11, \mathrm{CC} \rightarrow 12-1,36-40$ & $98.80-99.18$ & 98.98 \\
AP9/AP11 & $12-3,36-49 \rightarrow 12-7,36-40-\mathrm{UNC}$. & $102.18-108.18$ & 105.18 \\
AP7/AP9 & $13, \mathrm{CC} \rightarrow 14-1,36-40-\mathrm{UNC}$. & $118.30-118.88$ & 118.59 \\
AP6b/AP7 & $15-4,36-40 \rightarrow 15-4,110-114$ & $132.98-133.72$ & 133.35 \\
AP6a/AP6b & $15, \mathrm{CC} \rightarrow 16-1,36-40$ & $137.80-138.18$ & 137.98 \\
AP5/AP6a & $18-1,36-40 \rightarrow 18-3,110-114$ & $157.58-161.32$ & 159.45 \\
AP4/AP5 & $19-2,109-112 \rightarrow 19-4,36-39$ & $169.50-171.77$ & 170.64 \\
AP3/AP4 & $25-5,36-40$ & 210.58 & 210.58 \\
AP2/AP3 & $690 \mathrm{C}-12-1,38-42 \rightarrow 12, \mathrm{CC}$ & $214.30-218.06$ & 216.18 \\
AP2/AP1b & $13-2,38-42 \rightarrow 13-3,36-40$ & $225.50-226.98$ & 226.64 \\
AP1a/AP1b & $14-3,36-40 \rightarrow 14, \mathrm{CC}$ & $236.58-240.99$ & 238.79 \\
AP $\alpha / A P 1 a$ & $15-3,132-136 \rightarrow 15-4,28-30$ & $247.24-247.69$ & 247.47 \\
K/T & $15-4,35-37 \rightarrow 15-4,45-47$ & $247.76-247.81$ & 247.81 \\
A. mayaroensis/G. havanensis & $18, \mathrm{CC} \rightarrow 19-1,119-123$ & $278.37-282.31$ & 280.34 \\
G. havanensis/G. impensus & $22-2,118-122 \rightarrow 22-3,103-107$ & $312.18-314.15$ & 313.48 \\
\hline
\end{tabular}

Table 9. Sample levels in the cores and depth below seafloor for datum levels of benthic foraminifers, Site 689. UNC. = unconformity.

\begin{tabular}{lllr}
\hline \multicolumn{1}{c}{ Event } & \multicolumn{1}{c}{ Samples (Hole 689B) } & \multicolumn{1}{c}{$\begin{array}{l}\text { Depth } \\
\text { (mbsf) }\end{array}$} & Midpoint \\
\hline Assemblage 1/2 & $689 \mathrm{~B}-6-3,40-43 \rightarrow 6, \mathrm{CC}$ & $46.72-52.84$ & 49.78 \\
Assemblage 2/3 & $15-1,40-43 \rightarrow 15-2,40-43$ & $130.31-131.81$ & 131.06 \\
Assemblage 3/4a & $19-1,40-43 \rightarrow 19-2,40-43$ & $167.31-168.81$ & 168.06 \\
Assemblage 4a/4b & $22-2,40-43 \rightarrow 22-3,40-43$ & $199.41-200.91$ & 200.16 \\
Assemblage 4b/5 & $22-4,40-43 \rightarrow 22-5,40-43-$ UNC. & $202.41-203.91$ & 203.16 \\
Assemblage 5/6 & $23-1,40-43 \rightarrow 23-1,114-118$ & $207.61-208.36$ & 207.99 \\
Assemblage 6/7 & 24, CC $\rightarrow 25-1,99-100,103-U N C$. & $219.56-226.61$ & 223.59 \\
Assemblage 7/8 & $28-1,40-43 \rightarrow 28-2,40-43$ & $256.01-257.51$ & 256.56 \\
\hline
\end{tabular}

Table 10. Sample levels in the cores and depth below seafloor for datum levels of benthic foraminifers, Site 690 . UNC. = unconformity.

\begin{tabular}{|c|c|c|c|}
\hline Event & $\begin{array}{l}\text { Samples } \\
\text { Holes 689B, C }\end{array}$ & $\begin{array}{l}\text { Depth } \\
\text { (mbsf) }\end{array}$ & Midpoint \\
\hline Assemblage $1 / 2$ & $690 \mathrm{~B}-5-1,40-43 \rightarrow 5, \mathrm{CC}$ & $31.53-40.78$ & 36.16 \\
\hline Assemblage $2 / 3$ & $11-3,40-43 \rightarrow 11-4,40-43-$ UNC. & $92.51-94.01$ & 93.26 \\
\hline Assemblage $3 / 4$ & $12-6,40-43 \rightarrow 12$, CC-UNC. & $106.71-108.50$ & 107.61 \\
\hline Assemblage $4 \mathrm{a} / 4 \mathrm{~b}$ & $15-2,40-43 \rightarrow 15-2,74-76$ & $130.01-130.35$ & 130.18 \\
\hline Assemblage $4 \mathrm{~b} / 5$ & $15-4,40-43 \rightarrow 15-4,74-76-$ UNC.? & $133.01-133.35$ & 133.18 \\
\hline Assemblage $5 / 6$ & $19-3,40-43 \rightarrow 19-3,74-76$ & $170.31-170.65$ & 170.48 \\
\hline Assemblage $6 / 7$ & $690 \mathrm{C}-12-2,40-43 \rightarrow 12, \mathrm{CC}$ & $215.81-218.06$ & 216.94 \\
\hline Assemblage $7 / 8$ & $18-1,40-43 \rightarrow 18-2,40-43$ & 271.71-273.31 & 272.51 \\
\hline
\end{tabular}




\section{E. THOMAS ET AL.}

Table 11. Polarity reversal boundaries, following SpieB (this volume, chapter 21) for the Cenozoic, Hamilton (this volume) for the Mesozoic. Cenozoic data for Site $\mathbf{6 9 0}$ are from Hole $690 \mathrm{~B}$, Mesozoic data from Hole 690C. Depth below seafloor is the midpoint of two sample levels; the distance between two samples is usually $25 \mathrm{~cm}$.

\begin{tabular}{|c|c|c|c|}
\hline Event & $\begin{array}{l}\text { Age } \\
\text { (Ma) }\end{array}$ & $\begin{array}{l}\text { Site } 690 \\
\text { (mbsf) }\end{array}$ & $\begin{array}{l}\text { Site } 689 \\
\text { (mbsf) }\end{array}$ \\
\hline C7AR/C8N & 26.86 & 53.25 & 69.38 \\
\hline C8N2/C8R-2 & 27.74 & 60.11 & 75.98 \\
\hline C8R-2/C9N-1 & 28.15 & 60.99 & 79.46 \\
\hline C 9 N-1/2/C $9 \mathrm{R}-2$ & 29.21 & 68.48 & 85.05 \\
\hline C9R-2/C10N1/2 & 29.73 & - & 89.82 \\
\hline $\mathrm{C} 10 \mathrm{~N}-2 / \mathrm{C} 10 \mathrm{R}-2$ & 30.33 & - & 91.93 \\
\hline C10R-2/C11N-2 & 31.23 & - & 100.23 \\
\hline C11N-2/C11R-2 & 32.06 & 73.93 & 103.38 \\
\hline C11R-2/C12N & 32.46 & 80.76 & 104.38 \\
\hline $\mathrm{C} 12 \mathrm{~N} / \mathrm{C} 12 \mathrm{R}$ & 32.90 & 84.01 & 106.88 \\
\hline $\mathrm{C} 12 \mathrm{R} / \mathrm{C} 13 \mathrm{~N}-1$ & 35.29 & - & 116.71 \\
\hline $\mathrm{C} 13 \mathrm{~N}-1 / 2 / \mathrm{C} 13 \mathrm{R}-2$ & 35.87 & - & 119.70 \\
\hline $\mathrm{C} 13 \mathrm{R}-2 / \mathrm{C} 15 \mathrm{~N}-1 / 2$ & 37.24 & - & 124.09 \\
\hline C15N-1/2/C15R-2 & 37.68 & - & 125.07 \\
\hline C15R-2/C16N-1 & 38.10 & - & 128.33 \\
\hline $\mathrm{C} 16 \mathrm{~N}-3 / \mathrm{Cl} 16 \mathrm{R}-3$ & 39.24 & 95.70 & 134.02 \\
\hline C16R-3/C17N-1 & 39.53 & 96.59 & 135.77 \\
\hline $\mathrm{C} 17 \mathrm{R}-3 / \mathrm{C} 18 \mathrm{~N}-1 / 2$ & 41.29 & - & 153.70 \\
\hline C18R-3/C19N & 43.60 & - & 161.54 \\
\hline $\mathrm{C19N} / \mathrm{C} 19 \mathrm{R}$ & 44.06 & 105.65 & 163.16 \\
\hline $\mathrm{C} 19 \mathrm{R} / \mathrm{C} 20 \mathrm{~N}$ & 44.66 & 106.27 & 165.55 \\
\hline $\mathrm{C} 20 \mathrm{~N} / \mathrm{C} 20 \mathrm{R}$ & 46.17 & 118.23 & 171.11 \\
\hline $\mathrm{C} 20 \mathrm{R} / \mathrm{C} 21 \mathrm{~N}$ & 48.75 & 118.74 & 183.28 \\
\hline $\mathrm{C} 21 \mathrm{~N} / \mathrm{C} 21 \mathrm{R}$ & 50.34 & 123.63 & 197.89 \\
\hline $\mathrm{C} 21 \mathrm{R} / \mathrm{C} 22 \mathrm{~N}$ & 51.95 & 130.48 & - \\
\hline $\mathrm{C} 22 \mathrm{~N} / \mathrm{C} 22 \mathrm{R}$ & 52.62 & 132.23 & - \\
\hline C23N-2/C23R-2 & 54.70 & 133.18 & - \\
\hline C23R-2/C24N-1 & 55.14 & 137.33 & - \\
\hline $\mathrm{C} 24 \mathrm{~N}-1 / \mathrm{C} 24 \mathrm{R}-1$ & 55.37 & 139.67 & - \\
\hline C24R-1/C24N-2 & 55.66 & 144.42 & - \\
\hline $\mathrm{C} 24 \mathrm{~N}-2 / \mathrm{C} 24 \mathrm{R}-2$ & 56.14 & 154.63 & - \\
\hline $\mathrm{C} 24 \mathrm{R}-2 / \mathrm{C} 25 \mathrm{~N}$ & 58.64 & 185.48 & - \\
\hline $\mathrm{C} 25 \mathrm{~N} / \mathrm{C} 25 \mathrm{R}$ & 59.24 & 195.94 & - \\
\hline $\mathrm{C} 25 \mathrm{R} / \mathrm{C} 26 \mathrm{~N}$ & 60.21 & 210.20 & - \\
\hline $\mathrm{C} 26 \mathrm{~N} / \mathrm{C} 26 \mathrm{R}$ & 60.75 & 213.06 & - \\
\hline $\mathrm{C} 27 \mathrm{R} / \mathrm{C} 28 \mathrm{~N}$ & 64.29 & - & 228.61 \\
\hline $\mathrm{C} 29 \mathrm{~N} / \mathrm{C} 29 \mathrm{R}$ & 66.17 & 247.55 & - \\
\hline $\mathrm{C} 29 \mathrm{R} / \mathrm{C} 30 \mathrm{~N}$ & 66.74 & 252.58 & - \\
\hline $\mathrm{C} 30 \mathrm{~N} / \mathrm{C} 30 \mathrm{R}$ & 68.42 & - & 246.40 \\
\hline C30R/C31N & 68.52 & - & 248.08 \\
\hline $\mathrm{C} 31 \mathrm{~N} / \mathrm{C} 31 \mathrm{R}$ & 69.40 & 272.25 & 252.92 \\
\hline C31R/C32N & 71.37 & 283.39 & 259.97 \\
\hline $\mathrm{C} 32 \mathrm{~N} / \mathrm{C} 32 \mathrm{R}$ & 73.55 & 302.78 & 272.33 \\
\hline $\mathrm{C} 32 \mathrm{R} / \mathrm{C} 33 \mathrm{~N}$ & 74.30 & 308.02 & 277.32 \\
\hline
\end{tabular}

Table 12. Depth of Epoch boundaries recognized at Sites 689 and 690; numerical ages after Berggren et al. (1985), as emended by Aubry et al. (1988).

\begin{tabular}{lccr}
\hline \multicolumn{1}{c}{ Boundary } & $\begin{array}{c}\text { Site 689 } \\
\text { (mbsf) }\end{array}$ & $\begin{array}{c}\text { Site 690 } \\
\text { (mbsf) }\end{array}$ & $\begin{array}{r}\text { Age } \\
\text { (Ma) }\end{array}$ \\
\hline lower Pliocene/upper Miocene & 17.5 & 19.0 & 5.3 \\
upper Miocene/middle Miocene & 34.5 & 27.5 & 10.4 \\
middle Miocene/lower Miocene & 57.5 & 44.0 & 16.5 \\
lower Miocene/upper Oligocene & 67.0 & 52.5 & 23.7 \\
upper Oligocene/lower Oligocene & 91.0 & 72.0 & 30.0 \\
lower Oligocene/upper Eocene & 125.0 & 92.5 & 36.6 \\
upper Eocene/middle Eocene & 149.0 & 104.0 & 40.0 \\
middle Eocene/lower Eocene & - & 131.0 & 52.0 \\
lower Eocene/upper Paleocene & 202.0 & 165.0 & 57.0 \\
upper Paleocene/lower Paleocene & 227.0 & 226.5 & 62.3 \\
Paleocene/Cretaceous & 233.0 & 247.5 & 66.4 \\
upper/lower Maestrichtian & 257.0 & 280.0 & 69.4 \\
\hline
\end{tabular}

Unconformities at Site 690:

C6/C7 (20.45-26.56 Ma) between 51.15 and $51.40 \mathrm{mbsf}$ C9/C11 (29.73-31.96 Ma) between 72.05 and $72.30 \mathrm{mbsf}$ C12/C16 (33.92-38.73 Ma) between 91.33 and 91.83 mbsf C17/C19 (41.29-43.60 Ma) between 101.77 and $102.05 \mathrm{mbsf}$ C20/C21 (46.17-48.75 Ma) between 118.46 and $119.01 \mathrm{mbsf}$ C22/C23 (52.80-54.65 Ma) between 132.55 and 132.85 mbsf

Unconformities at Site 689:

C6/C7 (20.45-25.60 Ma) between 66.75 and $66.97 \mathrm{mbsf}$ C18R-2/C19N (42.80-43.66 Ma) between 161.30 and $161.77 \mathrm{mbsf}$ C21/C24 (51.07-56.14 Ma) at $203.00 \mathrm{mbsf}$ $\mathrm{C} 29 \mathrm{~N}$ on $\mathrm{C} 30 \mathrm{~N}(66.17-66.74 \mathrm{Ma})$ at $233.47 \mathrm{mbsf}$ 